\title{
O mundo da editoria digital entre estratégias de mercado e práticas revolucionárias
}

\author{
Giulia Crippa. \\ Livre Docente em Ciência da Informação pela Universidade de São Paulo - USP \\ Professora do Curso de Biblioteconomia e Ciências da Informação e da Documentação da Faculdade de \\ Filosofia, Ciências e Letras de Ribeirão Preto da Universidade de São Paulo - USP. \\ E-mail: giuliac@ffclrp.usp.br
}

GAZOIA, Alessandro. Come finisce il libro: contro la falsa democrazia dell'editoria digitale. Roma: Minimum Fax, 2014.

"Querido leitor" é o incipit do livro de Alessandro Gazoia que, como em uma longa conversa que cativa o leitor, propõe perguntas, reflexões e percursos para imaginar os possíveis futuros do livro, entendido como conteúdo a partir de sua forma, sobre a qual nos questionamos. Existe uma diferença entre livro impresso e digital? Entre publicação e autopublicação? Com esses questionamentos, o autor abre caminhos que esclarecem e desmascaram alguns dos mecanismos de uma pseudo democratização e libertação dos editores, que estão enriquecendo amplos setores da industria cultural, principalmente o grande colosso de Jeff Bezos, Amazon.

Todavia, elemento positivo no texto de Gazoia é que não se trata de um livro parcial. Não é aliado aos "entusiastas digitais" como o autor define aqueles que enfrentam muitas questões importantes de maneira ideológica, nem se coloca entre os adversários da editoria digital. Pelo contrario, oferece uma análise extremamente detalhada e cuidadosa que revela os lados positivos e negativos dos assuntos tratados, enfrentando cada um deles aprofundadamente, evidenciando todos seus aspectos com objetividade, ilustrando com clareza os mecanismos do sistema sobre o qual se fundamente a "revolução digital" sem levantar polêmicas espúrias nem teorias da conspiração. Nesse sentido, não é um livro "militante", em que o autor toma posição depois de individualizar os inimigos em Amazon, ou a salvação do livro no self-publishing:

Não tenho qualquer simpatia para as vítimas dos expurgos do pornô de Amazon quando escrevem livros horrendos que glorificam o estupro e propõem o incesto como variação sexual na moda, e não me interessa se aqueles autores autopublicados com essas obras «pagam o colégio aos filhos» (o segundo álibi para todo caminho nefasto da autopublicação, o primeiro são as contas), porém estar na frente de uma empresa de enorme poder que antes decide de maneira totalmente obscura o que é «ofensivo» e depois apaga arbitrariamente os livros não me parece uma grande conquista de liberdade e de independência. (GAZOIA, 2014, p. 37) ${ }^{1}$

\footnotetext{
1 Tradução nossa.
}

InCID: R. Ci. Inf. e Doc., Ribeirão Preto, v. 6, n. 2, p. 189-192, set. 2015/fev. 2016. 
Em trechos como esse, Gazoia revela a lucidez de suas análises, escapando de certa retórica que, quando se fala em livros e, ainda mais, em livros digitais, se faz presente muitas vezes, como quando se lê a respeito de self-publishing em termos do oferecimento de infinitas e inéditas possibilidades, ou de Amazon que permite adquirir um livro com um clique, o do ereader que, finalmente, permite carregar uma inteira livraria: todos jargões que não enfocam a revolução digital.

Gazoia relata, ilustra, explica ao longo de um livro que se torna uma descoberta agradável, alem de uma síntese e um avanço de tudo que aparenta ser relevante sobre o livro digital. Os debates principais são atualizados em todos os aspectos mais salientes. A matéria é dividida em três grandes capítulos: Publicar, Digital e Mitos/Social.

Adentramos, assim, em um território em que nas listas dos mais vendidos autores desconhecidos disputam seu lugar com o "Gotha" da literatura e as vendas se moldam, aparentemente, na base do gosto dos leitores ("o público vulcânico de Amazon [...] involuntariamente estava fazendo para mim um editing invejável"2. GAZOIA, 2014, p. 66).

O autor fala de self-publishing, da editoria paga, mas também de Jonathan Franzen e do Pêndulo de Foucault de Eco, que na década de 1980 já denunciava a fraude das editoras pagas pelos autores. Fala, também e acima de tudo, da política agressiva de Amazon e de como se constrói um organismo perfeitamente autossuficiente, desde a produção até os dispositivos de leitura, que torna, porém, inviável a transferência dos livros adquiridos no sistema lock-in, através do qual a maioria das empresas de tecnologia da informação construíram suas fortunas, um sistema em que, como enfocado na terceira parte, as modalidades de escrita e interação tornam os leitores aparentemente mais livres de manipular e interferir com os universos narrativos.

Come finisce il libro é um livro importante para quem deseja discutir e-book, bem como Amazon, distribuição, self-publishing, Wattpad e Dinosaur Erotica.

A história do livro digital, explica o autor, é imprescindível daquela de seu principal produtor e vendedor, Amazon, e o primeiro capítulo é dedicado ao colosso de Jeff Bezos, através de uma cuidadosa análise desenvolvida pelos cálculos econômicos, que mostra seu impacto no mercado editorial. O arrazoado se finca nas questões de descontos, de dinâmicas de

\footnotetext{
2 Idem.
} 
economia de mercado e de serviço ao consumidor, para se deslocar rumo a elementos menos evidentes mas bastante importantes. A atenção reservada ao consumidor, por exemplo, revela a importância da fidelização e da construção do sistema lock-in, em que Amazon explora o trabalho voluntário e gratuito dos próprios consumidores (e, nesse caso, bem lembra Gazoia da aquisição, por parte de Amazon, da plataforma social Goodreads). O sistema fechado de Amazon, que passa pelos sites de venda e pela fidelização aparentemente voluntária, porém, revela inúmeros problemas.

Com efeito, o discurso que autor tece evidencia os compromissos que existem, desde sempre, no mundo editorial, na sempre difícil busca de um equilíbrio entre obras literárias e best-sellers, se perguntando sobre os efeitos de um numero muito grande de obras produzidas por personagens do star system, mais do que por escritores. O autor lembra, assim, do difícil caminho que os novos autores precisavam seguir para serem publicados, para discutir, em seguida, a cada vez maior falta de filtros das obras autopublicadas. Aparentemente, o selfpublish em e-book, apoiada por exemplos famosos como o de E.L. James ou de Stephenie Meyer, legitima novos caminhos. Gazoia, porém, distingue, nessa questão, não o suporte, mas o uso que dele é feito. Do self-publish à democratização do processo de autoria o lapso é breve, tanto que o autor traz vários exemplos bem documentados, mas o caminho, alerta, é incerto, pois nesse processo se torna necessário redefinir o próprio conceito de literatura.

O livro de Gazoia não é um ensaio contra Amazon que, porém, enquanto ator principal da atual distribuição editorial, projeta sonhos, segue as transformações e se adéqua aos gostos dos consumidores. Constrói uma prisão invisível, em que o DRM obriga à fidelidade e abandonar o sistema significa perder o acesso aos conteúdos.

Gazoia conduz o leitor pelo panorama constituído pela fan fiction, pela produção e comercialização de produtos tie-in, como seriados, jogos, gadgets, HQs e tudo que orbita em volta de um universo narrativo original, observando a construção das mitologias dos produtos de massa que exploram o entusiasmo dos fãs com a finalidade do lucro das grandes empresas, revelando como essas operações constituem um único conjunto dentro um mundo autorreferencial no qual somente poucos são os títeres que movimentam as riquezas. A fan fiction é um território de enormes possibilidades, que goza de um público bastante amplo e ávido não somente de leituras, como de interações e recreações sem finalidade de lucro. Amazon criou sua fortaleza paga, através de Kindle Worlds, enredando leitores apaixonados e fieis. 
Gazoia, todavia, não delineia um cenário apocalíptico, nem desenha a editoria digital com tons derrotistas ou de acusação, limitando-se a iluminar alguns pontos sobre os quais os leitores e os aspirantes a autores devem refletir para fazer suas escolhas. De fato, fundamenta seu estudo em bases sólidas e ricas de dados (é impressionante a quantidade de notas de rodapé que auxiliam o leitor a seguir o fio da meada), e os percursos destacados possibilitam boas reflexões ao leitor sobre o que está acontecendo.

O autor destaca que a venda online de suportes digitais não é, por si, boa ou ruim. Não acusa as novas tecnologias, mas o uso que delas é feito, na medida em que deixam de ser instrumentos para uma vida melhor e passam a influenciar, de maneira às vezes invisível, os pensamentos e os hábitos dos leitores, encaminhando, ao mesmo tempo, a editoria rumo aos caminhos de um mais fácil sucesso, abandonando obras literárias consideradas muito complexas ou aqueles que não desejam se tornar parte desse organismo fechado.

Come finisce il libro não oferece soluções, mas analisa a situação atual, evidenciando e sublinhando aspectos pouco discutidos por aqueles que consideram o livro um objeto amado, para ler e ao qual dedicar uma parte de seu tempo. O ensaio se encerra com a simples consideração de que o futuro do livro, tão incerto no presente, deve conhecer a realidade atual e a ela se adaptar, sem perder, porém sua própria identidade. A literatura é algo complexo, e reduzi-la a simples estratégia comercial ameaça a consistência da cultura escrita.

Resenha enviada em: set. 2015

InCID: R. Ci. Inf. e Doc., Ribeirão Preto, v. 6, n. 2, p. 189-192, set. 2015/fev. 2016 